\title{
Enhanced cytotoxic effect of low doses of metformin combined with ionizing radiation on hepatoma cells via ATP deprivation and inhibition of DNA repair
}

\author{
JIFANG LIU ${ }^{1}$, MIN HOU $^{1}$, TAIZE YUAN ${ }^{2}$, GAO YI $^{3}$, SHUXU ZHANG ${ }^{2}$, XUNFAN SHAO $^{2}$, \\ JINHUI CHEN $^{4}$, XIAOTING JIA ${ }^{1}$ and ZHIMIN HE ${ }^{1}$
}

\begin{abstract}
${ }^{1}$ Cancer Research Institute and Cancer Hospital, Guangzhou Medical University; ${ }^{2}$ Department of Radiotherapy and
${ }^{3}$ Intensive Care Unit, Affiliated Tumor Hospital of Guangzhou Medical University, Guangzhou, Guangdong 510095;

${ }^{4}$ Department of Food and Drug, Qingyuan Polytechnic, Qingyuan, Guangdong 511515, P.R. China
\end{abstract}

Received June 13, 2012; Accepted July 16, 2012

DOI: $10.3892 /$ or.2012.1932

\begin{abstract}
Metformin, one of the most widely used antidiabetic drugs, has recently been associated with potential antitumorigenic effects. In this study, we evaluated the possible cytotoxic impact of combined low doses of metformin and ionizing radiation (IR) on 2 human hepatoma cell lines. The cytotoxic effect of metformin combined with IR was subsequently determined by clonogenic survival and cell cycle assays, assessment of mitochondrial complex I and lactate dehydrogenase (LDH) activity, measurement of cellular adenosine triphosphate (ATP) levels, comet assay and analyses of the formation and disappearance of phosphorylated histone $\mathrm{H} 2 \mathrm{AX}(\gamma-\mathrm{H} 2 \mathrm{AX})$ protein. The combination of metformin and IR caused a much stronger cytotoxicity than the treatment with metformin or IR alone, leading to an $\sim 80 \%$ decrease in cell viability and $\sim 35 \%$ increase in the accumulation of cells in the $\mathrm{G}_{2} / \mathrm{M}$ phase of the cell cycle in the 2 hepatoma cell lines. In addition, a reduction in mitochondrial complex I activity $(\sim 70 \%)$ and a significant increase in LDH activity, as well as lactate production were observed in the cells exposed to metformin. Interestingly, a severe depletion in ATP, increased olive tail moment and the delayed disappearance of $\gamma-\mathrm{H} 2 \mathrm{AX}$ expression were detected in the hepatoma cells treated by metformin plus IR. These findings show that the combination of a low concentration of metformin and IR results in the considerable enhancement of cytotoxic effects in human hepatoma cell lines, leading to decreased DNA repair by reducing ATP production. The data provided in this study may elucidate the remarkable efficiency of this combination treatment and suggest that metformin may
\end{abstract}

Correspondence to: Dr Zhimin He, Cancer Research Institute and Cancer Hospital, Guangzhou Medical University, Guangzhou, Guangdong 510095, P.R. China

E-mail: hezhimin2005@yahoo.com

Key words: metformin, ionizing radiation, hepatocellular carcinoma, adenosine triphosphate, DNA repair be used as a potential adjunct to the radiotherapy of hepatocellular carcinoma.

\section{Introduction}

Hepatocellular carcinoma (HCC) represents the 6th most common cancer and the 3rd leading cause of cancer death globally (1). More than $80 \%$ of HCC occurs in developing countries, particularly Southeast Asia and Africa. However, the incidence of HCC has recently been increasing in western countries. In the United States, HCC incidence rates increased by more than 2-fold between 1976 to 2002 and are expected to double over the next 2 decades (1,2). Although surgical resection, orthotopic liver transplantation and radiofrequency ablation form the cornerstone of curative treatment of HCC, patients should be treated within a multidisciplinary setting. HCC is generally regarded as not being sensitive to systemic chemotherapy. Other strategies such as transarterial chemoembolization (TACE) or sorafenib alone or combined radiotherapy provide only modest survival benefits. Due to low liver tolerance to radiation therapy, the role of radiotherapy in the management of HCC has traditionally been ignored (3). With developments of imaging techniques, conformal radiotherapy has allowed the delivery of a high dose of radiation to a precise tumor volume while sparing the surrounding normal liver parenchyma. However, survival after radiotherapy remains limited as a result of the high frequency of hepatic recurrences (4-6). Therefore, it is imperative to discover new therapeutics to improve survival in HCC patients.

Metformin ( $\mathrm{N}^{\prime}, \mathrm{N}^{\prime}$-dimethylbiguanide) is the most widely prescribed oral hypoglycemic agent. It is believed to exert its effect by reducing hepatic glucose production and by increasing insulin sensitivity and metabolism in peripheral tissues. Metformin has been successfully used in a wide variety of indications, such as in polycystic ovarian syndrome (PCOS) (7) and in the management of metabolic syndrome (8). Currently, increasing attention has been paid to metformin for its potential ability to suppress cancer cell growth. This has been demonstrated by multiple in vitro as well as in vivo studies $(9,10)$ and by its use in several randomized clinical trials as an adjuvant to conventional chemotherapeutic agents $(11,12)$. Although the 
mechanism of metformin anticancer action is not fully understood, there is substantial evidence indicating that metformin treatment activates AMP-activated protein kinase (AMPK), inhibits mTOR-dependent translation initiation (13-15) and affects cancer cell metabolism (16). Our previous study indicated that metformin exhibits protective effects on the metabolic disorder caused by a high-carbohydrate high-fat diet, which may shed light on its translational role in its antitumorigenic potential (17). Recently, epidemiological evidence has suggested that the anti-diabetic drug, metformin, reduces HCC risk and lowers the rates of cancer mortality among diabetics (18) without adverse side-effects. Metformin rarely causes lactic acidosis (19). However, little is known about the possible cytotoxic effects of metformin combined with radiotherapy in human hepatoma carcinoma.

In this study, we assessed the in vitro effect of the combination of metformin and ionizing radiation (IR) on hepatoma cell survival and explored the underlying mechanisms. Our data may contribute to the understanding of the mechanisms of action of the conventional drug and highlight potential implications of the combination of metformin and radiotherapy as an anticanc treatment.

\section{Materials and methods}

Chemicals and reagents. Metformin was purchased from Sigma Chemical Co. and dissolved in culture medium. RPMI-1640 medium, fetal bovine serum (FBS), $100 \mathrm{U} / \mathrm{ml}$ penicillin and $100 \mu \mathrm{g} / \mathrm{ml}$ streptomycin were obtained from Gibco. Antibodies used for western blot analyses were provided by Cell Signaling Technology, Inc. (Danvers, MA, USA).

Cell lines and treatment. Two human hepatoma cell lines (HepG2 and Bel-7402 cells with high and low invasive ability, respectively) were cultured in RPMI-1640 medium supplemented with $10 \% \mathrm{FBS}, 100 \mathrm{U} / \mathrm{ml}$ penicillin and $100 \mu \mathrm{g} / \mathrm{ml}$ streptomycin, at $37^{\circ} \mathrm{C}$ and $5 \% \mathrm{CO}_{2}$. The cells were a kind gift from Professor X. Guo (Sun Yat Sen University, Guangzhou, China). To evaluate the effect of the combination of metformin and IR, the cells were pre-incubated with $10 \mu \mathrm{M}$ metformin for $1 \mathrm{~h}$ and then exposed to various doses of radiation (0-5 Gy) using a Varian CL21EX accelerator (Varian Medical Systems, Palo Alto, CA, USA) with the source-skin-distance technique. The depth was set at $2 \mathrm{~cm}$ to the bottom of the 6-well plate.

Clonogenic assay. Cells were seeded in 6-well plates in triplicates at a density of 1,000 cells/well in $2 \mathrm{ml}$ of medium containing $10 \%$ FBS. After $24 \mathrm{~h}$, the cells were treated with metformin $(10 \mu \mathrm{M})$ followed by IR (1, 2 and $5 \mathrm{~Gy}$, separately) and grown for 2 weeks. The cell clones were fixed and stained for 15 min with a solution containing $0.5 \%$ crystal violet and $25 \%$ methanol, followed by 3 rinses with tap water to remove the excess dye. Colonies containing $>50$ cells were counted.

Cell cycle analysis. Cells $\left(1 \times 10^{6}\right)$ were seeded in 6-well plates in triplicates. After $24 \mathrm{~h}$, cells were treated with metformin $(10 \mu \mathrm{M})$ for $1 \mathrm{~h}$ followed by IR (2 Gy). After $36 \mathrm{~h}$, the cells were harvested by trypsinization and fixed with $70 \%$ ethanol. The cells were stained for total DNA content with a solution containing $50 \mu \mathrm{g} / \mathrm{ml}$ propidium iodide and $100 \mu \mathrm{g} / \mathrm{ml}$ RNase I in PBS for $30 \mathrm{~min}$ at $37^{\circ} \mathrm{C}$. The cell cycle distribution was then analyzed in a FACSCalibur cytometer (BD Bioscience, Mountain View, CA, USA).

Determination of mitochondrial complex I and glycolytic activity. Complex I activity was determined using the Dipstick Assay kit (MitoSciences, Eugene, OR, USA) according to the manufacturer's instructions. The cellular glycolytic activity was evaluated by measuring the activity of the key enzyme, lactate dehydrogenase (LDH) and lactate production. LDH activity was monitored spectrophotometrically by measuring the increase in NADH at $340 \mathrm{~nm}$ produced in the reaction of lactate to pyruvate as described previously (20). Lactate concentration in the culture medium was assessed with a chromatometric kit obtained from Sigma.

Measurement of cellular adenosine triphosphate (ATP) concentration. An ATP assay kit was purchased from the Beyotime Institute of Biotechnology (Haimen, China). The process was performed according to the manufacturer's instructions. Harvested cultured cells were lysed with a lysis buffer, followed by centrifugation at $12,000 \mathrm{xg}$ for $5 \mathrm{~min}$ at $4^{\circ} \mathrm{C}$. Finally, the level of ATP was determined by mixing $100 \mu \mathrm{l}$ of the supernatant with $100 \mu$ l luciferase reagent, which catalyzed the light production from ATP and luciferin. The emitted light was linearly associated with the ATP concentration and measured using a luminometer (Promega, Madison, WI, USA).

Comet assay. The comet assay was performed under alkaline conditions as previously described $(21,22)$, with minor modifications. Briefly, HepG2 and Bel-7402 cell suspension was separately mixed with low-melting agarose at $1 \times 10^{4}$ cells $/ \mathrm{ml}$ at $37^{\circ} \mathrm{C}$ and evenly pipetted into the microscope slides pre-coated with $250 \mu \mathrm{l}$ of $0.6 \%$ normal high-melting agarose. The slides were maintained on ice for $10 \mathrm{~min}$ to solidify. The remaining cells were exposed to metformin $(10 \mu \mathrm{M})$ for $1 \mathrm{~h}$ followed by IR ( 2 Gy). After $1 \mathrm{~h}$, the treated cells were washed with ice-cold PBS and spread on the slides as described above. The slides were then immersed in chilled lysis solution $(2.5 \mathrm{M} \mathrm{NaCl}$, $100 \mathrm{mM} \mathrm{Na}_{2}$ EDTA, $10 \mathrm{mM}$ Tris- $\mathrm{HCl}, 1 \%$ Triton $\mathrm{X}-100$ and $10 \%$ DMSO, $\mathrm{pH} 10.0$ ) at $4^{\circ} \mathrm{C}$ for $2 \mathrm{~h}$ in the dark. Thereafter, the slides were rinsed in freshly prepared and chilled electrophoresis buffer ( $1 \mathrm{mM} \mathrm{Na}_{2}$ EDTA, $300 \mathrm{mM} \mathrm{NaOH}$ and $\mathrm{pH}>13.0$ ) for $20 \mathrm{~min}$ to allow DNA unwinding. Electrophoresis was then performed at $22 \mathrm{~V}, 300 \mathrm{~mA}$ at $4^{\circ} \mathrm{C}$ for $20 \mathrm{~min}$. The slides were washed with a neutralizing buffer $(0.4 \mathrm{M}$ Tris- $\mathrm{HCl}$ and $\mathrm{pH} 7.5)$ 3 times and then stained with $30 \mu$ l ethidium bromide $(5 \mu \mathrm{g} / \mathrm{ml})$ for $15 \mathrm{~min}$. Images of the comets were captured under a fluorescence microscope (Leica CTR6000) at x100 magnification. For each sample, a minimum of 50 comets was obtained and the olive tail moment [tail DNA (\%) x (tail mean - head mean)] was analyzed using the Comet Assay Software Project (CASP).

Western blot analysis. Cell lysates were prepared in a buffer containing $0.5 \mathrm{mM}$ Tris $\mathrm{HCl}(\mathrm{pH} 7.0), 0.1 \% \beta$-mercaptoethanol, $0.5 \mathrm{mM}$ EDTA (pH 7.0), $0.5 \mathrm{mM}$ EGTA (pH 7.0), $2 \mathrm{mM}$ leupeptin, $1 \mathrm{mM}$ PMSF, $2.5 \mathrm{mg} / \mathrm{ml}$ aprotinin, $1 \mathrm{mM}$ DTT and $0.5 \%$ Triton $\mathrm{X}-100$. After protein quantification using the Bradford assay, $25 \mu \mathrm{g}$ of proteins were separated by SDS-PAGE and transferred onto nitrocellulose membranes (Amersham 

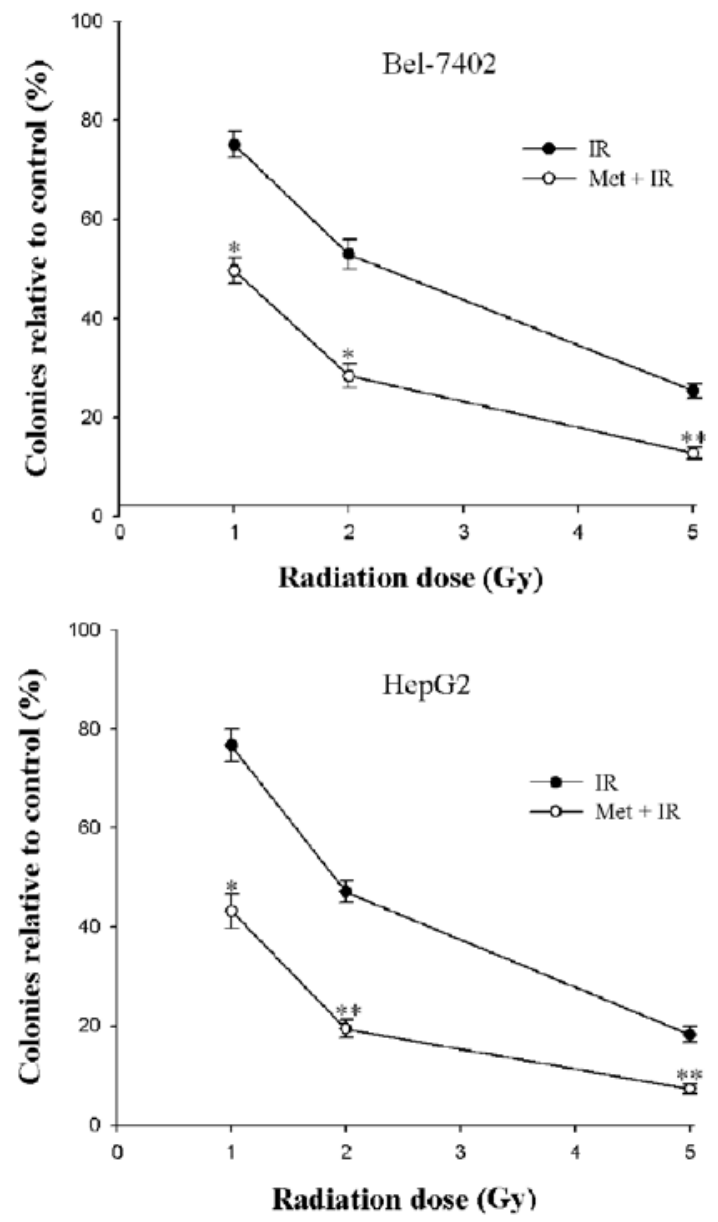

Figure 1. Effect of the combination of metformin and IR on cell survival. Bel-7402 and HepG2 cells were irradiated with 1, 2 and 5 Gy X-rays after being exposed to $10 \mu \mathrm{M}$ metformin for $1 \mathrm{~h}$. Data represent the average values of 3 independent experiments \pm SD. The colonies were stained by crystal violet 10-14 days later. Values are normalized to those of the untreated cells. IR, ionizing radiation; Met + IR, metformin combined with IR. ${ }^{*} \mathrm{P}<0.05,{ }^{* *} \mathrm{P}<0.01$, compared with IR treatment.

Life Sciences, Piscataway, NJ, USA). The membranes were blocked using PBS (pH 7.4) containing 5\% not-fat milk for $1 \mathrm{~h}$, probed with primary antibody phospho-H2AX (Ser139) [antiphosphorylated histone $\mathrm{H} 2 \mathrm{AX}(\gamma-\mathrm{H} 2 \mathrm{AX})]$ overnight at $4^{\circ} \mathrm{C}$. The membranes were then washed with PBST (PBS $+0.1 \%$ Tween-20) and incubated with a HRP-conjugated secondary antibody (Santa Cruz Biotechnology, Inc., Santa Cruz, CA, USA) for $1 \mathrm{~h}$. Immunoreactive proteins were detected using an enhanced chemiluminescence detection reagent from BestBio Co. (Shanghai, China). The membranes were stripped and reprobed with anti-H2AX and anti- $\beta$-actin antibodies.

Statistical analysis. Data analyses were carried out using SPSS V17.0 and GraphPad Prism 4 software with the Student's t-test. The results are expressed as the means \pm SEM or SD. A difference was considered statistically significant when $\mathrm{P}<0.05$.

\section{Results}

Effect of metformin plus IR on cancer cell viability. To determine the effects of metformin in combination with IR on hepatoma
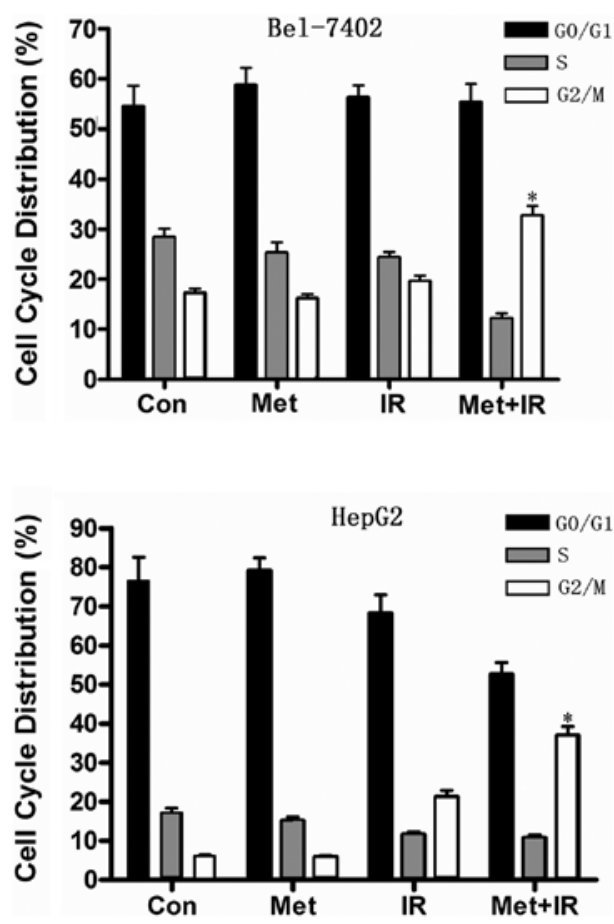

Figure 2. Effect of metformin combined with IR on the cell cycle profile in 2 hepatoma cells. Bel-7402 and HepG2 cells were starved overnight and exposed to metformin for $1 \mathrm{~h}$ before irradiation with $2 \mathrm{~Gy}$ X-rays. After $36 \mathrm{~h}$, cell cycle analysis was performed by flow cytometry. Con, control; Met, metformin; IR, ionizing radiation; Met + IR, metformin combined with IR. Data are the means $\pm \mathrm{SEM}, \mathrm{n}=3$. $\mathrm{P}<0.05$, compared with individual treatment.

cell viability, we observed the ability of the 2 cell lines to form colonies on 6-well plates. IR caused a dose-dependent inhibition of colony formation in Bel-7402 and HepG2 cells (Fig. 1). A statistically significant enhancement of the radiation response was found in the 2 cell lines after treatment with metformin $(\mathrm{P}<0.05)$ (Fig. 1). These results demonstrated that the inhibitory effect caused by the combination of metformin and IR on cell survival was more effective than IR alone. Moreover, metformin combined with 5 Gy X-ray radiation was found to provide the best results with respect to the enhancement of cytotoxicity as opposed to a lower irradiation dose. As regards clinical radiotherapy, the dose of $2 \mathrm{~Gy}$ was selected to fulfill the following experiment.

Combination of metformin and IR blocks the cell cycle in the $G_{2} / M$ phase. To determine whether the decrease in cell viability induced by the combination of metformin and IR is associated with cell cycle arrest, we analyzed the cell cycle phase distribution in the 2 hepatoma cell lines. Bel-7402 and HepG2 cells treated for $1 \mathrm{~h}$ in the presence of metformin were irradiated with $2 \mathrm{~Gy} \mathrm{X}$-rays and subjected to flow cytometric analysis $36 \mathrm{~h}$ later. Metformin treatment resulted in a minor accumulation of hepatoma cells in the $\mathrm{G}_{0} / \mathrm{G}_{1}$ phase (Fig. 2). Importantly, the combination of metformin and IR notably disturbed the cell cycle progression and showed a dramatic increase in the $\mathrm{G}_{2} / \mathrm{M}$ phase cell populations in the hepatoma cells compared with metformin or IR treatment alone (Fig. 2), which may in part account for the strong inhibition of cell viability induced by $\mathrm{G}_{2} / \mathrm{M}$ arrest. 
A

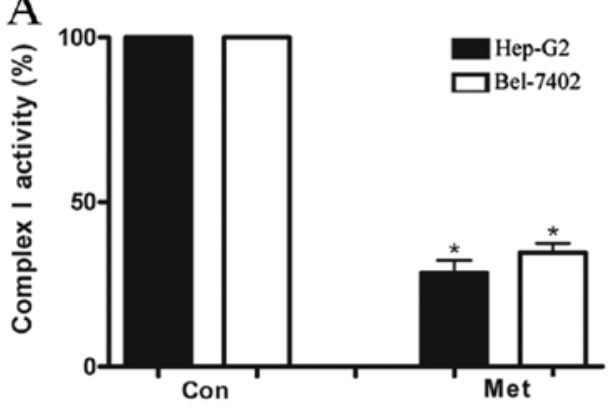

$\mathrm{C}$

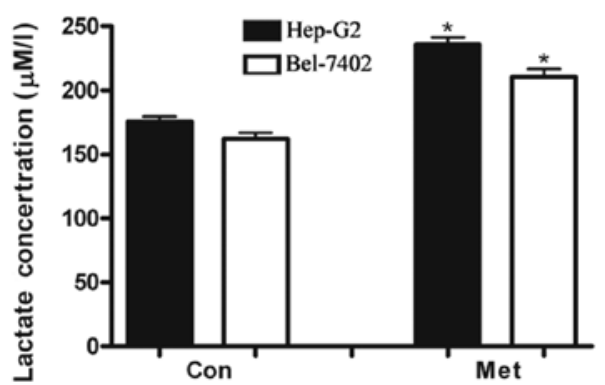

B

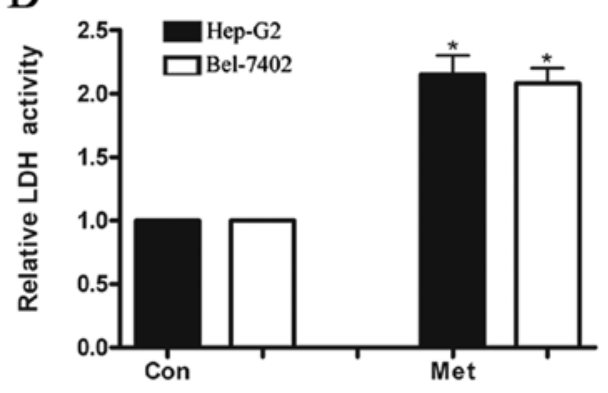

D

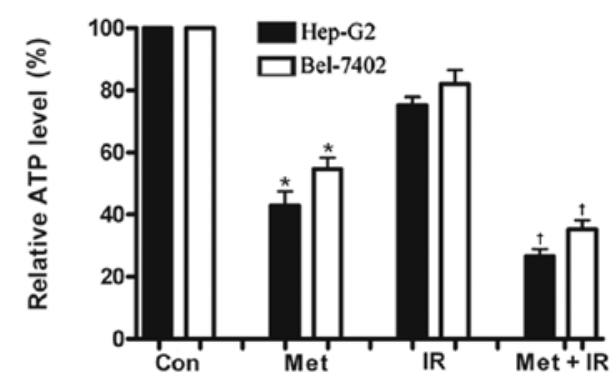

Figure 3. Effects of metformin combined with IR on hepatoma cell energy metabolism. (A) Changes in mitochondrial complex I activity in response to metformin treatment. The control value was set at 100\%. (B) Comparision of cellular LDH activity. LDH activity was expressed relative to the control. The control value was presented as 1. (C) Lactate concentration in the medium after treatment with $10 \mu \mathrm{M}$ metformin. (D) Intracellular ATP levels in hepatoma cells. Cells were incubated with metformin $(10 \mu \mathrm{M})$ for $1 \mathrm{~h}$ followed by IR (2 Gy). After 24h, ATP levels were assayed. Con, control; Met, metformin; IR, ionizing radiation; Met $+\mathrm{IR}$, metformin combined with IR. Data are presented as the means \pm SEM from 3 experiments. ${ }^{*} \mathrm{P}<0.05$, compared with the control; ${ }^{\dagger} \mathrm{P}<0.05$, compared with IR.

Metformin combined with IR initiates a strong energy stress in hepatoma cells. To investigate whether metformin has an effect on hepatoma cell energy metabolism, mitochondrial complex I activity that is involved in ATP generation was measured in a panel of 2 human malignant hepatoma cell lines. Metformin diminished mitochondrial respiratory chain complex I activity by 72 and $65 \%$ in HepG2 and Bel-7402 cells, respectively (Fig. 3A). As it has been known, a decrease in oxidative phosphorylation is equivalent to a nutrient depletion in terms of ATP supply which forces cells to improve their bioenergetics, such as increased glycolysis and autophagy $(23,16)$. Hepatoma cells treated with metformin produced a significantly greater level of LDH activity (a key enzyme involved in glycolysis and catalyzing the conversion of pyruvate to lactate) and lactate accumulation than the untreated cells (Fig. 3B and C) $24 \mathrm{~h}$ after treatment. However, the ATP level was greatly diminished in both cell lines after treatment with metformin (Fig. 3D). These results indicated that as a consequence of complex I inhibition, metformin significantly enhanced the glycolytic ability of the hepatoma cells to compensate ATP deprivation from the mitochondrial respiratory defect. Increased glycolytic activity is unable to produce enough compensatory ATP eventually leading to cell death as the ATP generation by glycolysis is less efficient than by mitochondrial oxidative phosphorylation (2 vs. 36 ATP/glucose). To evaluate the effects on cell energy metabolism induced by IR, cellular ATP production was determined in hepatoma cells. A small decrease in ATP levels was observed in hepatoma cells $24 \mathrm{~h}$ post-irradiation, while the combination of metformin and IR decreased ATP concentration by $>70 \%$ in HepG2 cells and $\sim 60 \%$ in Bel-7402 cells, suggesting that metformin plus IR initiate a strong energy stress in hepatoma cells compared with IR treatment (Fig. 3D).

Increased DNA damage induced by metformin combined with $I R$. To further investigate how metformin plus IR treatment decrease cell survival, we performed a comet assay to ascertain DNA damage. The combination treatment significantly increased the olive tail moment in the 2 hepatoma cell lines compared to each individual treatment $(\mathrm{P}<0.05)$ (Fig. 4).

Enhanced expression of $\gamma-H 2 A X$ protein in response to metformin plus IR treatment. The $\gamma-\mathrm{H} 2 \mathrm{AX}$ protein was infrequently expressed in the control HepG2 cells (Fig. 5A). Treatment with $10 \mu \mathrm{M}$ of metformin alone led to a minor increase in $\gamma$-H2AX expression, $1 \mathrm{~h}$ after treatment. Moderate levels of $\gamma$-H2AX protein were observed $1 \mathrm{~h}$ after irradiation with 2 Gy. More importantly, when the HepG2 cells were treated with $10 \mu \mathrm{M}$ of metformin for $1 \mathrm{~h}$ prior to treatment with 2 Gy X-rays, the protein expression of $\gamma$-H2AX was dramatically increased compared with either metformin or IR treatment alone. Surprisingly, an obvious diminution of the expression of the $\gamma-\mathrm{H} 2 \mathrm{AX}$ protein in HepG2 cells was observed $24 \mathrm{~h}$ after treatment with metformin or radiation alone, showing that DNA damage, likely the presence of double-strand breaks (DSBs), was repaired. By contrast, the combination of metformin plus radiation significantly prolonged the expression of $\gamma-\mathrm{H} 2 \mathrm{AX}$ $24 \mathrm{~h}$ after treatment, with more breaks remaining unrepaired. A similar difference was also observed when the Bel-7402 cells were assayed for $\gamma$-H2AX (Fig. 5B). However, the total H2AX expression levels remained almost unaltered (Fig. 5). These 

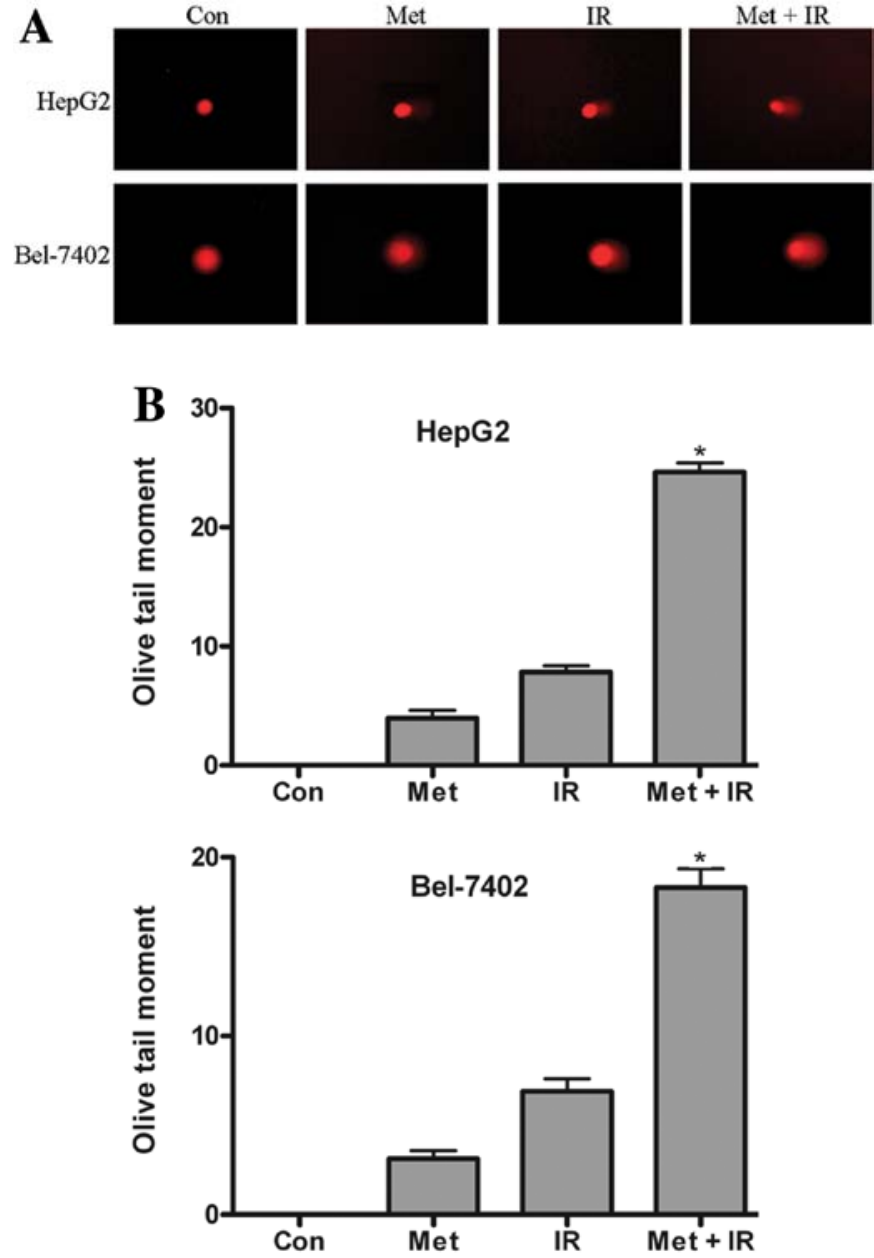

Figure 4. Effect of metformin combined with IR on DNA damage in hepatoma cells. (A) Representive results of comet assay to detect DNA damage (original magnification, x100). (B) Olive tail moments were measured using the Comet 5.5 software. Values are the means \pm SEM. Con, control; Met, metformin; IR, ionizing radiation; Met + IR, metformin combined with IR. ${ }^{*} \mathrm{P}<0.05$, compared with metformin or IR alone.

results revealed that metformin enhanced tumor radiosensitivity in vitro and this sensitization correlated with the augmentation in DNA damage and the delayed disappearance of $\gamma$-H2AX expression, suggesting an inhibition of the repair of constitutive DNA damage.

\section{Discussion}

HCC is a highly lethal cancer with a poor prognosis. Radiotherapy has long been excluded from the therapeutic strategy for HCC due to its significant toxic effects on the normal liver parenchyma. With the development of radiation therapy equipment and technology, radiotherapy has become one of the main non-surgical treatments for HCC. However, increasing the dose of radiation is unfeasible to the majority of patients with advanced HCC having serious liver diseases, such as hepatitis and cirrhosis. Thus, more efficient and safe agents should be developed to increase the radiosensitivity of HCC (24). Therefore, the present study was carried out to address the effects of metformin in combitation with IR on human hepatoma cells and to investigate the possible mechanisms involved.
A
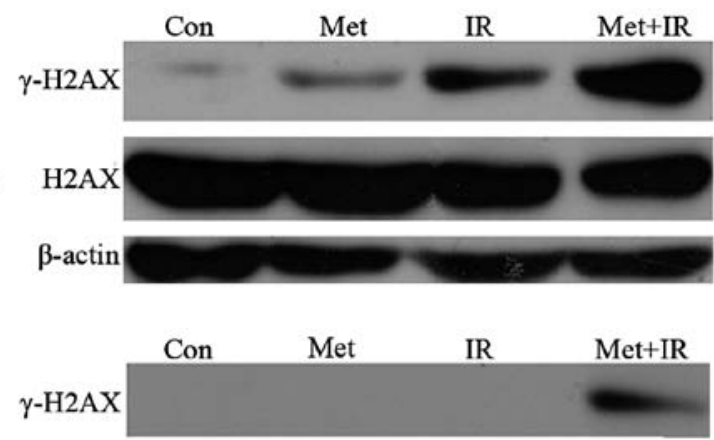

$24 \mathrm{~h}$

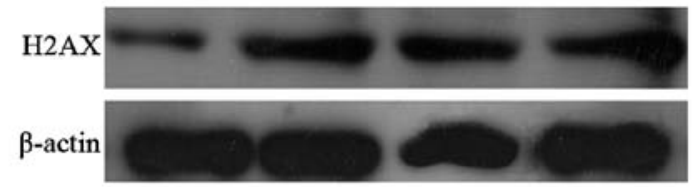

HepG2

B

$1 \mathrm{~h}$

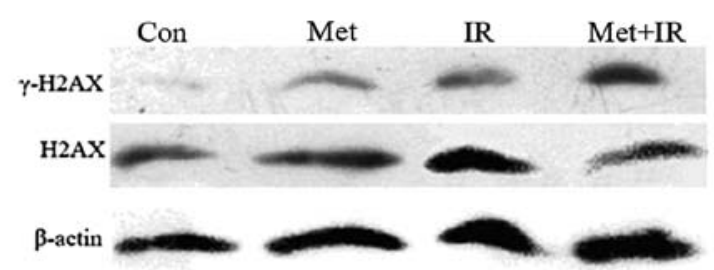

$24 \mathrm{~h}$

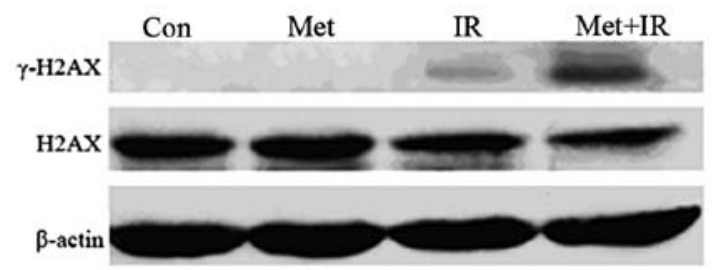

Bel-7402

Figure 5. Expression analyses of the $\gamma-\mathrm{H} 2 \mathrm{AX}$ protein in hepatoma cells (A and B) Representative results of the protein expression of $\gamma-\mathrm{H} 2 \mathrm{AX}$ and total H2AX by western blot analysis at 1 and $24 \mathrm{~h}$ after treatment in HepG2 and Bel-7402 cells, respectively. $\gamma$-H2AX, phosphorylated histone H2AX; $\beta$-actin, internal control protein; Con, control; Met, metformin; IR, ionizing radiation; Met + IR, metformin combined with IR.

In this study, the low doses of metformin in combination with X-ray radiation demonstrated an obvious enhancement of cytotoxicity in the 2 hepatoma cell lines. To the best of our knowledge, an investigation of the radiosensitizing potential of the combination of metformin and X-ray radiation has not yet been reported, although metformin has recently been reported to modify $\gamma$-ray response in lung cancer (25). Based on our results, metformin significantly enhanced the radiation response, as the number of colonies of hepatoma cells in the combined treatment group was significantly lower than that of each individual treatment group, implying that metformin may function as a potential radiation sensitizer for cancer radiotherapy.

The results of metformin combined with X-ray radiation are promising. However, the underlying mechanisms by which metformin exhibits its effects and interacts with X-ray radiation are largely unknown. 
A possible explanation may be related to the changes in DNA repair. The cellular genome is constantly exposed to exogenous and endogenous DNA damage. DNA is regarded as the major target of IR. IR-induced DNA damage, including base damage, sugar damage, single-strand breaks (SSBs) and DSBs, of which DSBs are generally accepted as the most relevant lesion for the deleterious effect of IR. In response to DNA damage, the histone $\mathrm{H} 2 \mathrm{AX}$ at the break site is phosphorylated at serine 139 by DNA damage sensor kinases, such as ataxia telangiectasia-mutated (ATM), forming $\gamma$-H2AX. Previous biochemical studies have revealed that $\gamma$-H2AX plays an essential role in the recruitment of other proteins to repair the breaks. After DNA damage is repaired by homologous recombination or non-homologous endjoining, $\gamma-\mathrm{H} 2 \mathrm{AX}$ is dephosphorylated and the cell survives (26). Additionally, $\gamma$-H2AX expression has been shown to disappear more rapidly in radiation-resistant tumor cells than in radiationsensitive cells $(27,28)$. In the present study, the combination of metformin with X-ray radiation remarkably induced DNA damage in the 2 hepatoma cell lines, suggesting that radiosensitivity with metformin may result from the augmentation of $\mathrm{X}$-ray-induced DNA damage. Interestingly, the disappearance of $\gamma-\mathrm{H} 2 \mathrm{AX}$ expression was slower in the group treated with metformin plus $\mathrm{X}$-ray radiation than in the group treated with radiation or metformin alone, indicating that the radiosensitizing effects of metformin may be due to the impaired repair of DNA damage, which was consistent with previous observations that the inhibition of DNA repair was a possible cause of the enhancement of the radiation response $(29,30)$. However, how metformin inhibits the repair process of DNA damage is yet to be determined. According to previous studies, DNA repair is an energy-demanding process $(31,32)$. If damage is excessive and the ATP concentration drops to a low level, it may exterminate cells whose damaged DNA can not be successfully repaired (33). The present study provides evidence suggesting that the depletion of ATP may be a contributing factor linked to the impairment of DNA repair. Since pre-treatment with metformin resulted in severe ATP reduction in the hepatoma cells (Fig. 3D), this may have impeded DNA repair, as ATP is required for this repair. Thus, a decrease in ATP levels could lead to persistent DNA damage or decreased cell survival to a greater extent due to X-ray radiation. Additional investigations are required to further elucidate the molecular processes responsible for metformin mediated radiosensitization.

It is striking to observe a minor increase in the expression of $\gamma-\mathrm{H} 2 \mathrm{AX}$ after $1 \mathrm{~h}$ of treatment with $10 \mu \mathrm{M}$ metformin but not after $24 \mathrm{~h}$. Our findings concur with the recent observation of Halicka et al (34), who reported that metformin treatment for 24-48 $\mathrm{h}$ decreased rather than increased the level of the constitutive expression of $\gamma-\mathrm{H} 2 \mathrm{AX}$, possibly by decreasing oxidative stress (34). Possibly the same mechanism is involved in the reduction of $\gamma-\mathrm{H} 2 \mathrm{AX}$ expression after treatment with metformin for $1 \mathrm{~h}$ as compared for $24 \mathrm{~h}$.

In addition, the doses of metformin used in previous in vitro experiments including breast (35), pancreas (36), prostate (37), colon (16), lung (38) and ovary cancer cells (39), varied from 0.1 to $30 \mathrm{mM}$, which is $\sim 5$ to 1,500 -fold higher than the recommended therapeutic dose (in clinical pharmacokinetic studies, investigators have calculated $20 \mu \mathrm{M}$ as a clinically equivalent dose in vitro) (40-42). It is therefore quite difficult to deduce the results obtained from in vitro studies and the potential effects of metformin in clinical trials with a standard metformin dosage. Therefore, for our study, the cytotoxicity of various concentrations of metformin $(0,1,2,5,10,20$ and $50 \mu \mathrm{M})$ was previously determined using a clonogenic assay in hepatoma cells. We found that the appropriate dosage of metformin for the colony formation in these cells was $\sim 10 \mu \mathrm{M}$ (data not shown). Thus, this dose was used in our study.

To the best of our knowledge, our study proves for the first time that the brief exposure of hepatoma cells to metformin at a micromolar concentration prior to IR significantly enhances the radiation responses by inhibiting DNA repair. The data from our study may provide the scientific foundation for further in vivo cancer models and clinical studies as regards the combination of metformin and radiotherapy for HCC treatment.

\section{Acknowledgements}

This study was supported by grants (A2011290) from the Department of Health of Guangdong Province, (2012J2200032) from the Star of Science and Technology of Guangzhou, and (20121A011163) from Health Bureau of Guangzhou. We gratefully acknowledge Dr Y.X. Gu and W.J. Zhang from the Central South University for their helpful comments during the study.

\section{References}

1. El-Serag HB and Rudolph KL: Hepatocellular carcinoma: epidemiology and molecular carcinogenesis. Gastroenterology 132: 2557-2576, 2007.

2. El-Serag HB, Davila JA, Petersen NJ and McGlynn KA: The continuing increase in the incidence of hepatocellular carcinoma in the United States: an update. Ann Intern Med 139: 817-823, 2003.

3. Dawson LA, Normolle D, Balter JM, McGinn CJ, Lawrence TS and Ten Haken RK: Analysis of radiation-induced liver disease using the Lyman NTCP model. Int J Radiat Oncol Biol Phys 53: 810-821, 2002.

4. Mornex F, Girard N, Beziat C, Kubas A, Khodri M, Trepo C and Merle P: Feasibility and efficacy of high-dose threedimensional-conformal radiotherapy in cirrhotic patients with small-size hepatocellular carcinoma non-eligible for curative therapies - mature results of the French Phase II RTF-1 trial. Int J Radiat Oncol Biol Phys 66: 1152-1158, 2006.

5. Girard N and Mornex F: External radiotherapy for hepatocellular carcinoma. Cancer Radiother 15: 49-53, 2011.

6. Liang SX, Zhu XD, Lu HJ, et al: Hypofractionated three-dimensional conformal radiation therapy for primary liver carcinoma. Cancer 103: 2181-2188, 2005.

7. Diamanti-Kandarakis E, Economou F, Palimeri S and Christakou C: Metformin in polycystic ovary syndrome. Ann NY Acad Sci 1205: 192-198, 2010.

8. Bianchi C, Penno G, Romero F, Del Prato S and Miccoli R: Treating the metabolic syndrome. Expert Rev Cardiovasc Ther 5: 491-506, 2007.

9. Evans JM, Donnelly LA, Emslie-Smith AM, Alessi DR and Morris AD: Metformin and reduced risk of cancer in diabetic patients. BMJ 330: 1304-1305, 2005.

10. Kourelis TV and Siegel RD: Metformin and cancer: new applications for an old drug. Med Oncol 29: 1314-1327, 2012.

11. Tennant DA, Durán RV and Gottlieb E: Targeting metabolic transformation for cancer therapy. Nat Rev Cancer 10: 267-277, 2010.

12. Ben Sahra I, Le Marchand-Brustel Y, Tanti JF and Bost F: Metformin in cancer therapy: a new perspective for an old antidiabetic drug? Mol Cancer Ther 9: 1092-1099, 2010.

13. Zakikhani M, Dowling RJ, Sonenberg N and Pollak MN: The effects of adiponectin and metformin on prostate and colon neoplasia involve activation of AMP-activated protein kinase. Cancer Prev Res (Phila) 1: 369-375, 2008.

14. Dowling RJ, Zakikhani M, Fantus IG, Pollak M and Sonenberg N: Metformin inhibits mammalian target of rapamycin-dependent translation initiation in breast cancer cells. Cancer Res 67: 10804-10812, 2007. 
15. Hardie DG: Adenosine monophosphate-activated protein kinase: a central regulator of metabolism with roles in diabetes, cancer, and viral infection. Cold Spring Harb Symp Quant Biol 76: 155-164, 2011.

16. Buzzai M, Jones RG, Amaravadi RK, et al: Systemic treatment with the antidiabetic drug metformin selectively impairs p53-deficient tumor cell growth. Cancer Res 67: 6745-6752, 2007.

17. Hou M, Venier N, Sugar L, et al: Protective effect of metformin in CD1 mice placed on a high carbohydrate-high fat diet. Biochem Biophys Res Commun 397: 537-542, 2010.

18. Hassan MM, Curley SA, Li D, et al: Association of diabetes duration and diabetes treatment with the risk of hepatocellular carcinoma. Cancer 116: 1938-1946, 2010.

19. Lalau JD and Race JM: Lactic acidosis in metformin therapy. Drugs 1: 55-60, 1999.

20. Vanderlinde RE: Measurement of total lactate dehydrogenase activity. Ann Clin Lab Sci 15: 13-31, 1985.

21. van Dyk E and Pretorius PJ: DNA damage and repair in mammalian cells exposed to p-hydroxyphenylpyruvic acid. Biochem Biophys Res Commun 338: 815-819, 2005.

22. Gu YX, Fan SS, Xiong Y, et al: Cloning and functional characterization of TCRP1, a novel gene mediating resistance to cisplatin in an oral squamous cell carcinoma cell line. FEBS Lett 585: 881-887, 2011.

23. Ortega AD, Sánchez-Aragó M, Giner-Sánchez D, SánchezCenizo L, Willers I and Cuezva JM: Glucose avidity of carcinomas. Cancer Lett 276: 125-135, 2009.

24. Rahbari NN, Mehrabi A, Mollberg NM, Müller SA, Koch M, Büchler MW and Weitz J: Hepatocellular carcinoma: current management and perspectives for the future. Ann Surg 253: 453-469, 2011

25. Sanli T, Rashid A, Liu C, et al: Ionizing radiation activates AMP-activated kinase (AMPK): a target for radiosensitization of human cancer cells. Int J Radiat Oncol Biol Phys 78: 221-229, 2010.

26. Kinner A, Wu W, Staudt C and Iliakis G: Gamma-H2AX in recognition and signaling of DNA double-strand breaks in the context of chromatin. Nucleic Acids Res 36: 5678-5694, 2008.

27. Judit PB, Susan HM and Peggy LO: Radiation sensitivity, H2AX phosphorylation, and kinetics of repair of DNA strand breaks in irradiated cervical cancer cell lines. Cancer Res 64: 7144-7149, 2004.

28. Klokov D, MacPhail SM, Banáth JP, Byrne JP and Olive PL: Phosphorylated histone $\mathrm{H} 2 \mathrm{AX}$ in relation to cell survival in tumor cells and xenografts exposed to single and fractionated doses of X-rays. Radiother Oncol 80: 223-229, 2006.
29. Raju U, Nakata E, Yang P, Newman RA, Ang KK and Milas L: In vitro enhancement of tumor cell radiosensitivity by a selective inhibitor of cyclooxygenase-2 enzyme: mechanistic considerations. Int J Radiat Oncol Biol Phys 54: 886-894, 2002.

30. Huang G, Wang $\mathrm{H}$ and Yang LX: Enhancement of radiationinduced DNA damage and inhibition of its repair by a novel camptothecin analog. Anticancer Res 30: 937-944, 2010.

31. Petermann E, Ziegler M and Oei SL: ATP-dependent selection between single nucleotide and long patch base excision repair. DNA Repair 2: 1101-1114, 2003.

32. Lammens K, Bemeleit DJ, Mockel C, et al: The Mre11:Rad50 structure shows an ATP-dependent molecular clamp in DNA double-strand break repair. Cell 145: 54-66, 2011.

33. Lyamzaev KG, Izyumov DS and Avetisyan AV: Inhibition of mitochondrial bioenergetics: the effects on structure of mitochondria in the cell and on apoptosis. Acta Biochim Pol 51: 553-562, 2004.

34. Halicka HD, Zhao H, Li JW, Traganos1 F, Zhang SF, Lee M and Darzynkiewicz1 Z: Genome protective effect of metformin as revealed by reduced level of constitutive DNA damage signaling. Aging 3: 1-11, 2011.

35. Hirsch HA, Iliopoulos D, Tsichlis PN and Struhl K: Metformin selectively targets cancer stem cells, and acts together with chemotherapy to block tumor growth and prolong remission. Cancer Res 69: 7507-7511, 2009.

36. Kisfalvi K, Eibl G, Sinnett-Smith J and Rozengurt E: Metformin disrupts crosstalk between $\mathrm{G}$ protein-coupled receptor and insulin receptor signaling systems and inhibits pancreatic cancer growth. Cancer Res 69: 6539-6545, 2009.

37. Ben Sahra I, Laurent K, Loubat A, et al: The antidiabetic drug metformin exerts an antitumoral effect in vitro and in vivo through a decrease of cyclin D1 level. Oncogene 27: 3576-3586, 2008.

38. Algire C, Zakikhani M, Blouin MJ, Shuai JH and Pollak M: Metformin attenuates the stimulatory effect of a high-energy diet on in vivo LLC1 carcinoma growth. Endocr Relat Cancer 15: 833-839, 2008.

39. Rattan R, Giri S, Hartmann LC and Shridhar V: Metformin attenuates ovarian cancer cell growth in an AMP-kinase dispensable manner. J Cell Mol Med 15: 166-178, 2011

40. Scheen AJ: Clinical pharmacokinetics of metformin. Clin Pharmacokinet 30: 359-371, 1996.

41. Isoda K, Young JL, Zirlik A, et al: Metformin inhibits proinflammatory responses and nuclear factor-kappaB in human vascular wall cells. Arterioscler Thromb Vasc Biol 26: 611-617, 2006.

42. Graham GG, Punt J, Arora M, et al: Clinical pharmacokinetics of metformin. Clin Pharmacokinet 50: 81-98, 2011. 